\title{
Richard Pipes: historyk „imperium zła”
}

17 maja 2018 r. w Bostonie zmarł Richard Pipes, emerytowany profesor Uniwersytetu Harvarda, jeden z największych historyków XX w., zaszczycający od 2013 r. Komitet Naukowy „Studiów z Dziejów Rosji i Europy Środkowo-Wschodniej” swoim udziałem. Dożył stulecia bolszewickiego przewrotu, którego naturę opisał bardziej wnikliwie niż ktokolwiek przed nim (czy po nim). Zabrakło mu dwóch miesięcy do 95. urodzin - a pół roku do setnej rocznicy narodzin II Rzeczypospolitej, którą zawsze wspominał jako kraj szczęśliwych lat dziecinnych.

Historia jego życia zaczęła się w lipcu 1923 r. w Cieszynie. Jego ojciec, Marek, wywodzący się z lwowskiej rodziny zasymilowanych Żydów, w czasie I wojny służył w legionach Piłsudskiego, a po wojnie prowadził w mieście nad Olzą interes cukierniczy - ten sam, który do dziś eksportuje na cały świat wafelki Prince Polo. Wraz z rodziną (matka małego Rysia, Zofia z Haskelbergów, pochodziła podobnie jak ojciec z rodziny żydowskiej, tyle że z chasydzkiej rodziny z zaboru rosyjskiego) przeniósł się następnie do Warszawy. Tam przyszły historyk uczęszczał do elitarnego gimnazjum Kreczmara. Językiem domowym Pipesów był niemiecki. Polski stał się drugim językiem przyszłego krytyka „imperium zła”, językiem szkoły, rozmów i zabaw z kolegami na basenie "Legii”, rodzinnych wycieczek - od Lwowa i Krakowa po Ciechocinek. Interesował się malarstwem europejskim, historią sztuki. Marzył o studiach na Uniwersytecie Warszawskim. Ale tego marzenia nie zrealizował. Dopadła go historia.

Vixi - tak brzmi oryginalny tytuł wydanych 15 lat temu wspomnień Richarda Pipesa. Nasuwa się porównanie z cezariańskim Veni, vidi, vici. U Profesora Pipesa brzmiałoby to raczej: Vidi, veni, vixi - „zobaczyłem, przybyłem, przeżyłem”. Młody chłopiec z żydowskiej, stosunkowo zamożnej i w znacznym stopniu już zasymilowanej rodziny, zobaczył totalitaryzm na własne oczy, zanim został jego badaczem. To był totalitaryzm w niemieckim, hitlerowskim wydaniu. Wraz z rodzicami Richard Pipes zdołał opuścić Warszawę (na fałszywych, boliwijskich paszportach) w końcu października 1939 r. i przedostać się przez Włochy, Hiszpanię i Portugalię 
do USA. Dalsza część jego rodziny, z Krakowa, Lwowa, Warszawy, została jednak wymordowana przez niemieckich zbrodniarzy. Tego Richard Pipes nigdy nie mógł zapomnieć. Została w nim do końca życia awersja do niemieckości. Sam zdążył jeszcze obejrzeć ze zgrozą los barbarzyńsko zbombardowanej polskiej stolicy i zobaczyć, zza firanki, defiladę butnego Wehrmachtu w Warszawie, przyjmowaną osobiście przez Adolfa Hitlera. Jego świadomość historyczna wiązać będzie odtąd Pipesa bardziej z indywidualnymi ofiarami niż z potężnymi zwycięzcami geopolitycznej czy ideologicznej rywalizacji. Jak sam napisał w swoich pamiętnikach: „Głównym efektem wpływu Holocaustu na moją psychikę był codzienny zachwyt życiem, które zostało mi darowane, ponieważ zostałem uratowany od pewnej śmierci. Czułem i czuję po dziś dzień, że zostałem ocalony nie po to, by marnować moje życie na folgowaniu sobie, ani na własnej karierze tylko, ale by głosić moralne przesłanie poprzez wskazywanie, przy użyciu przykładów z historii, jak zła idea prowadzi do złych konsekwencji. Ponieważ uczeni napisali już dosyć dzieł o Holocauście, uznałem za moją misję ukazywanie tej prawdy poprzez używanie przykładu komunizmu."

Przywołanie wrażenia, jakie w rodzinie Pipesów przyniosła wiadomość o zawarciu paktu Ribbentrop-Mołotow - pierwsza scena wspomnień historyka - nie pozostawia jednak wątpliwości, że na świadomości przyszłego profesora Harvardu już od 23 sierpnia tamtego roku położył się nader realny cień dwóch totalitaryzmów, które wszczęly II wojnę. Osobiste zetknięcie z grozą przemocy rozpętanej przez Stalina i Hitlera było dla Pipesa trwałym doświadczeniem, które nie pozwoliło mu nigdy ulec pokusom historycznego rewizjonizmu, doszukującego się jakichś „pozytywnych stron” w doświadczeniu tego totalitaryzmu, który rok 1945 przetrwał - systemu sowieckiego. Nigdy nie będzie szukał moralnych usprawiedliwień dla jakiegoś „mniejszego zła”, co narazi go na - opisywany w wielu fragmentach wspomnień - ostracyzm dużej części środowiska „postępowej” sowietologii.

Dzięki łutowi szczęścia, mógł przybyć we właściwym czasie we właściwe miejsce, by zając się wnikliwym studium drugiego z totalitarnych szaleństw XX w.: rosyjskiego komunizmu. Dotarłszy w czasie wojny do Ameryki, Pipes został $\mathrm{w}$ ramach służby wojskowej skierowany na kurs rosyjskiego na Uniwersytecie Cornella. Tam też w dosłownie romantyczny sposób natknął się na swoją przyszłą żonę: Irenę Roth, ze zasymilowanej do polskości rodziny żydowskiej z Warszawy. Młody Pipes poznał ją, słuchając nagranego przez jej koleżankę na płytę fragmentu Mickiewiczowego Pana Tadeusza. Przez to nagranie i jego autorkę trafił właśnie na Irenę - i połączył się z nią małżeńskim węzłem na, jak się okazało, przeszło 70 lat... Oparcie w tym związku na całe życie dawać mu będzie wielką siłę znoszenia krytyki, czasem nawet obelg, jakich nie będą mu szczędzili miłośnicy komunizmu, tak bardzo wpływowi w amerykańskim świecie akademickim.

Do owego świata Pipes wchodził w szczególnym momencie. Kiedy rozpoczął studia historyczne na Uniwersytecie Harvarda, miał okazję wysłuchać 5 czerwca 1947 r. wykładu, jaki wygłaszał wówczas sekretarz stanu USA, George Marshall: 
był to wykład poświęcony planowi odbudowy Europy, wykład tego, co przyjmie się odtąd nazywać planem Marshalla. Pipes wiedział jednak, że za granicą tego planu, pod władzą Stalina pozostawiona została połowa Europy, jego rodzinnej Europy. Początkom sowieckiej polityki zniewalania narodów poświęcił Pipes swoją rozprawę doktorską, obronioną w 1950 r., a opublikowaną cztery lata później: Formation of the Soviet Union. Nationalism and Communism, 1917-1924.

To, że trwała w owym czasie w wielkiej geopolitycznej grze Zimna Wojna, nie oznacza bynajmniej, że sympatycy "dobrego wujka Joe” zniknęli wówczas z życia akademickiego. Gdy chodzi o ściśle rozumiane studia nad systemem sowieckim, to wśród obowiązkowych lektur na Harvardzie były wciąż takie choćby tytuły, jak Sir Johna Maynarda Russia in Flux, która podtrzymywała nonsensy o Stalinie jako dobrotliwym ojcu swego narodu. Książka Rudolfa Schlesingera Spirit of Post-war Russia, opublikowana w 1948 r. - a porównująca stalinowską konstytucję z 1936 r. do konstytucji amerykańskiej, z wyraźnym uznaniem wyższości tej pierwszej była traktowana jako jedno z najbardziej autorytatywnych dzieł z zakresu studiów sowieckich w świecie anglosaskim.

To nie były jedynie ślady sojuszu i przyjaźni z czasu II wojny i fascynacji wąsatym „Uncle Joe” (takie fascynacje nie umierają z dnia na dzień). Inne motywy miały także istotne znaczenie. Dotyczyły one relacji między akademickimi instytucjami i moralnymi osądami, abstrakcyjnymi teoriami i politycznymi realiami tego czasu. Wydaje się charakterystyczne, że Russian Research Center, najważniejsza w następnych dekadach instytucja zajmująca się naukowo systemem sowieckim i Rosją, ustanowiona na Harvardzie w 1948 r., została powierzona w fazie organizacyjnej kierownictwu znakomitego znawcy... Indian Navajo, antropologowi, Clydowi Kluckhohnowi. Jego celem jako dyrektora Centrum miało być „odejście od polityki i historii, i podejście do Związku Sowieckiego jako do «systemu»: systemu, który - niezależnie od tego, co kto o nim sądzi - udowodnił swoją efektywność przez sam fakt swojego przetrwania [...] przez lata społecznych wstrząsów i wojny". Jak ujmie to później jeden z badaczy zatrudnionych na Harvardzie, „przeciętny anglo-amerykański uczony piszący w tamtym okresie o Związku Sowieckiego podchodził do takich kategorii jak państwo policyjne, terror, czy totalitaryzm z takim samym drżeniem i obrzydzeniem, z jakim powieściopisarz epoki wiktoriańskiej zbliżał się do miejsca, w którym musiał uczynić aluzję do seksualnego aktu".

Prawdziwy pomnik takiej tendencji, z pozoru obiektywnej, a w istocie sprzyjającej sowieckiemu wielkiemu kłamstwu, wystawił wówczas brytyjski historyk, Edward Hallett Carr. Oksfordzki politolog, a wcześniej dyplomata, gorący entuzjasta appeasementu, czyli oddania całej Europy Środkowo-Wschodniej Hitlerowi, po II wojnie był uznawany za najwybitniejszego na Zachodzie znawcę Związku Sowieckiego. Teraz Carr uważał, że cała Europa Środkowo-Wschodnia należy się Stalinowi - ponieważ to Stalin i jego czołgi są "nosicielami postępu” w tej zacofanej części kontynentu. W takim też duchu - bezkrytycznej chwalby sowieckiego „eksperymentu” - opublikował Carr w 1950 r. pierwszy (z czternastu!) tom swojej 
Historii Rosji Sowieckiej. I wtedy właśnie młodziutki badacz z Cieszyna rzucił rękawicę uznanemu guru rodzącej się „sowietologii”.

28-letni doktorant opublikował miażdżącą recenzję z pierwszego tomu syntezy Carra - na łamach poważnego pisma naukowego, „Russian Review” (dzięki pomocy Michaela Karpovicha, najbardziej wpływowego z członków Rady Redakcyjnej pisma, a zarazem promotora przygotowywanej przez Pipesa na Harvardzie rozprawy doktorskiej). Historia nie może być tylko apologią zwycięzców - stwierdzał Pipes. Jeśli Lenin i jego towarzysze zdobyli władzę nad Rosją w 1917-1919 r., a w latach 1939-1945 Stalin poszerzył to panowanie na pół Europy jeszcze, to ich sukces nie dowodzi bynajmniej, że mają rację. Trzeba w historii oddawać głos także, a może przede wszystkim, ofiarom. O nich zaś Carr milczał. „Trudno sobie wyobrazić bardziej dogłębne odseparowanie moralności od historii niż to, które prezentuje niniejsza książka" - podsumował swoją krytykę tej tendencji młody Pipes. Historia powinna opowiadać przebieg zdarzeń - a nie tylko projektować wizję pewnego "porządku”. Historyk powinien oceniać, zarówno świadectwa - selekcjonując je według kryterium ich weryfikowalności - jak też dramatis personae swojej narracji. Dlaczego? Ponieważ jest to narracja ludzkich dramatów, a nie akademicki eksperyment. Historyk powinien unikać deterministycznych ujęć, a także - ostatecznie - powinien ujawnić zdolność do współczucia: nie tylko ze zwycięzcami. Nie da się odseparować jakąś ścianą historii ludzi i moralnych osądów. Tak, w skrócie w recenzji Pipesa - wyglądał program przyszłej, alternatywnej syntezy rosyjskiej rewolucji, jaką stworzy autor tej recenzji czterdzieści lat później.

Nie znaczy to wcale, iż Richard Pipes zdecydował się na "świętą wojnę" z komunizmem od początku swojej kariery naukowej. Choć jego stanowisko było już jasno określone w 1950 r., kiedy pisał recenzję dzieła Carra, pracował jednak w swym zawodzie przede wszystkim jako sumienny historyk Rosji. I z tej właśnie perspektywy krytykował Carra jako politologa, który wkroczył na teren historii i uprościł jej złożoną materię za pomocą metod i wzorów pozwalających raczej konstruować systemy i modele aniżeli rozumieć działania i motywacje poszczególnych ludzi, jak też ich historyczne uwarunkowania. Pipes jako historyk nie miał ani Marksa ani Hegla za swojego patrona (gdyby jakiegoś można było mu w ogóle przypisać, byłby to pewnie Tykidydes, z jego zdolnością do rozumienia pełnych pasji, nie tylko racjonalnych, ale także irracjonalnych motywów wielkich wydarzeń).

Dalsze studia historyczne Pipesa: wspomniane Formation of the Soviet Union. Nationalism and Communism (1954), książki o głównym ideologu konserwatyzmu rosyjskiego Nikołaju Karamzinie (1959), o ruchu robotniczym w Petersburgu (1963), potem monumentalna, dwutomowa biografia Piotra Struvego, myśliciela i polityka liberalnej Rosji (1970 i 1980) - zbudowały pozycję ich autora jako jednego z najwybitniejszych specjalistów w zakresie historii Rosji XIX i początku XX w. Poziom naukowy prac Pipesa pozwolił mu wygrać konkurs na stanowisko profesora historii Rosji na Uniwersytecie Harvarda w roku 1958 - i to stanowisko będzie zajmował aż do emerytury, do roku 1996. Harvardzki Russian Research 
Center dzięki niemu przede wszystkim wyrósł w tym okresie do rangi najpoważniejszego, najbardziej twórczego ośrodka badań nad historią Rosji i Związku Sowieckiego. Pipes objął funkcję dyrektora tego ośrodka, którą przez ponad dwadzieścia pięć lat sprawował na przemian z innym wielkim przedstawicielem „polskiej szkoły" w amerykańskiej sowietologii, wychodźcą z przedwojennego Lwowa, Adamem Ulamem.

„Nie wolno wierzyć refleksjom Polaków o Rosji i ZSRR, oni nie myślą uczciwie" - tak przedstawiciel innego zgoła nurtu sowietologii amerykańskiej, profesor Moshe Lewin, ostrzegał amerykańską publiczność przed kolejnymi książkami Pipesa jeszcze w 1991 r. Na czym polegała owa „polska specyfika” spojrzenia na Rosję i komunizm, którą w owej etnicznej obeldze „zdemaskował” Lewin (nota bene, także urodzony w Polsce...)? Zrozumieć ją można nie tylko poprzez lekturę tekstów samego Pipesa, Ulama, czy Zbigniewa Brzezińskiego, ale poprzez przypomnienie kontekstu ideowego, w którym ich głosy były przyjmowane, a raczej odrzucane w świecie amerykańskiej, a szerzej - zachodniej - sowietologii. Kontekst ten tworzyło od lat sześćdziesiątych zdecydowane zwycięstwo nurtu, który reprezentował m.in. wspomniany Moshe Lewin: nurtu tzw. rewizjonistów, którzy w imię „obiektywizmu badawczego" zaczęli doszukiwać się pozytywnych stron sowieckiego „eksperymentu”. Rewizjoniści podkreślali „demokratyczny” charakter sowieckiego państwa, jego „sprawiedliwy” społecznie system dystrybucji dóbr, skuteczność w rozwiązywaniu problemów narodowościowych, podnoszeniu poziomu kulturalnego mas, budowaniu względnego przynajmniej dobrobytu. Minimalizując ofiary, jakie pociągnęło za sobą budowanie owej sowieckiej utopii, rewizjoniści podkreślali zdecydowanie „prawo” narodów ZSRR do budowania alternatywnego wobec kapitalizmu sposobu życia.

Richard Pipes już po pierwszej swojej wizycie w ZSRR, w 1957 r., nie miał żadnych wątpliwości, że zgoła inne prawa: do wolności słowa, wolności religii, do własności - a raczej brak tych praw - są przeżywane głęboko przez zwyczajnych mieszkańców „Kraju Rad”. Jednocześnie, tak jak Ulam i Brzeziński, wyniósł Pipes z Polski instynktowne niemal doświadczenie ekspansjonizmu sowieckiego (rozwiniętego na gruncie bogatej pod tym względem tradycji rosyjskiej). Związek Sowiecki był w tej perspektywie, w perspektywie Pipesa, wrogiem: groźnym wrogiem Zachodu; wrogiem, który jednak miał swoją wewnętrzną, zasadniczą słabość - sprzeczność z naturalnymi dążeniami olbrzymiej części swoich poddanych. Ten pogląd był dla rewizjonistów absolutną herezją, a głosząca go mniejszość - oskarżana o „zimnowojenne instynkty”, ,jaskiniowy antykomunizm” - przedmiotem środowiskowego ostracyzmu.

Pozycję Pipesa jako „parszywej owcy” amerykańskiej sowietologii umocniła zdecydowanie jego synteza historii Rosji przedrewolucyjnej - Russia under the Old Regime (1974, u nas wydana, w podziemnym wydawnictwie, pod tytułem Rosja carów) - szukająca konsekwentnie korzeni sowieckiego totalitaryzmu w Rosji carskiej jeszcze. Książka ta, rzeczywiście nader bliska w swej głównej idei tradycjom 
polskiej interpretacji ciągłości „białego i czerwonego caratu” (najpełniej wyłożonej przez Jana Kucharzewskiego), spotkała się także z ostrymi polemikami ze strony sowieckich propagandystów, jak i rosyjskiej emigracji - z Aleksandrem Sołżenicynem na czele.

W tym samym czasie Pipes wystąpił wobec waszyngtońskich polityków z ostrzeżeniem przed lekceważeniem ofensywnej atomowej strategii sowieckiej; przedstawiając zasadniczą krytykę polityki detente - realizowanej od czasów Nixona do Cartera linii ustępstw amerykańskich w stosunku do ekspansywnej polityki ZSRR. Nieustępliwie krytykował tę cyniczną i krótkowzroczną politykę, jaką w Waszyngtonie promował jego niegdysiejszy kolega z Harvardu - Henry Kissinger.

Pipes zaangażował się w polityczną działalność jako konsultant senatora Henry'ego Jacksona w prowadzonej przez niego kampanii przeciw błędom polityki detente. W 1976 r. stanął na czele „Team B”, grupy niezależnych specjalistów, powołanej przez prezydenta Geralda Forda do oceny tej analizy polityki i strategii sowieckiej, jaką dostarczała rządowi amerykańskiemu CIA. Zespół kierowany przez Richarda Pipesa (pod jego opieką stawiali w tym zespole pierwsze polityczne kroki tak znani później gracze amerykańskiej sceny strategicznej, jak Paul Nitze czy Paul Wolfowitz) wykazał, że sowieccy stratedzy nie dążą do osiągnięcia równowagi, ale do osiągnięcia zasadniczej przewagi nuklearnej nad Stanami Zjednoczonymi. „Team B” przedstawił sugestię, zgodnie z którą owa sowiecka strategia powinna spotkać się ze zdecydowanym przeciwdziałaniem ze strony Ameryki. Kiedy w 1976 r. raport zespołu przedostał się do prasy, Pipes zyskał rozgłos jako jeden $\mathrm{z}$,jastrzębi” w polityce Waszyngtonu. Cztery lata później, po wyborczym zwycięstwie Ronalda Reagana, zaproszony został przez nowego prezydenta do Narodowej Rady Bezpieczeństwa (National Security Council), jako kierownik Wydziału Europy Wschodniej i Związku Sowieckiego. Profesor Pipes wziął dwuletni urlop z Harvardu, służąc w NSC do końca 1982 r. Był uważany za jednego z architektów „twardej” polityki administracji Reagana w tym okresie wobec Związku Sowieckiego - tej polityki, którą symbolizowało określenie ZSRR przez amerykańskiego prezydenta jako „evil empire” (imperium zła). Na pewno był także Richard Pipes głównym konstruktorem polityki sankcji amerykańskich wobec reżimu Jaruzelskiego po wprowadzeniu w Polsce stanu wojennego. Po powrocie do Harvardu, Pipes kontynuowal swe polityczne zainteresowania w formie komentarzy na temat aktualnej polityki Moskwy i stosunków amerykańsko-sowieckich (zebrane w 1984 r. w formie książki: Survival Is Not Enough). Przedstawiał nadal swoje opinie na temat sytuacji w Rosji i stosunków amerykańsko-rosyjskich w najbardziej prestiżowych magazynach opinii amerykańskiej i międzynarodowej.

Przełom lat osiemdziesiątych i dziewięćdziesiątych pozwolił Pipesowi na chwilę triumfu: polityka stanowczego przeciwstawienia się komunistycznej ekspansji, wspierania ruchów opozycyjnych ( $\mathrm{z}$ „Solidarnością” na czele) wewnątrz „imperium zła” przyniosła swoje owoce. Wskazywane przez Pipesa fundamentalne słabości wewnętrzne sowieckiej potęgi dały o sobie znać. „Demokratyczny” według większości 
amerykańskich sowietologów, cieszący się „masowym poparciem społecznym” system sowiecki - runął. Otwarte dzięki temu archiwa Moskwy pozwoliły ponad wszelką wątpliwość odsłonić nieludzki charakter tegoż systemu, potwierdzić skalę jego ofiar.

Ofiarom systemu właśnie zadedykował Pipes swoje opus magnum: wydaną w 1990 r. syntezę rewolucji rosyjskiej (Russian Revolution). Refleksji nad pozostałościami tego systemu w mentalności jego poddanych, nad dziedzictwem komunizmu poświęcił dalsze lata swoich studiów, które kontynuował już jako profesor emeritus. Pojawi się w serii tych studiów trzeci tom swoistej trylogii: po Rosji starego reżimu i Rewolucji rosyjskiej - Rosja nowego reżimu (1993), opisująca utwierdzenie bolszewików u władzy w latach 1919-1924. Potem kolejne błyskotliwe analizy fenomenu komunizmu i rewolucji.

Instytut Noblowski w Oslo zaprosił w 1993 r. Pipesa do wygłoszenia wykładów, co jest jedyną namiastką Nagrody Nobla dla przedstawicieli nauk humanistycznych. Pipes wykorzystał tę prestiżową okazję do podsumowania swej analizy. Komunizm, stwierdził w swych noblowskich wykładach, próbował zanegować trzy fundamentalne składniki ludzkiej natury: przywiązanie do prywatnej własności, do religii i do wolności słowa. To ostatecznie skazało go na ekonomiczną klęskę, a także na duchową pustkę, nie wykorzeniając przy tym tęsknoty ludzi - ofiar systemu - za utraconymi wartościami.

Wartości te, uważał Pipes, są jednak nadal zagrożone - także wewnątrz cywilizacji zachodniej. W Rosji źródłem tego zagrożenia było (i jest) państwo, w dzisiejszych Stanach Zjednoczonych czy w Europie jest nim opinia „elity”, która uporczywie atakuje własność, religię i wolność słowa. Dowodem na to stałe podnoszenie podatków pod dyktando „mediokracji” i jej pupilów - lewicowych polityków, traktujących indywidualne bogactwo (naturalnie nie własne) jako niemoralne, dążących do przekazania maksimum bogactwa narodowego w ręce rządowej biurokracji. Dowodem na to także stała agresja dominujących mediów i hołubionych w nich „elit intelektualnych” wobec zjawiska odradzania się religii i wszelkich prób podtrzymania moralnego fundamentu życia publicznego. Dowodem na to wreszcie fenomen political correctness, w którym znikoma mniejszość stara się narzucić ogromnej większości społeczeństwa swoją sprzeczną ze zdrowym rozsądkiem ortodoksję. Na tym właśnie (między innymi) polegał bolszewizm. I o tym przypominał całym dziełem swego życia Richard Pipes.

Miałem zaszczyt znać Profesora od roku 1991, kiedy to mogłem go odwiedzić po raz pierwszy na Uniwersytecie Harvarda. Zawsze elegancki, „pod krawatem” (tak nieczęsty to widok wśród obecnych wykładowców amerykańskich uczelni), wydawał się jakby zdystansowany wobec otaczającej go rzeczywistości. Był, z bliższej perspektywy, serdecznym, życzliwym człowiekiem. Coraz bardziej, w ostatnich latach, zwracał się ku swej polskiej przeszłości, ku wspomnieniom raju lat dziecinnych. W ostatnich latach, zwierzył mi się, zdarzało mu się coraz częściej zapominać słów angielskich - w głowie starego człowieka odzywały się wtedy polskie słowa i nazwy. Przyjeżdżał więc chętnie do Polski po 1991 r., zawsze razem 
z Małżonką, gorącą orędowniczką dobrej pamięci o latach polsko-żydowskiego współżycia. Sam Profesor nigdy nie przyłączył się do chóru ataków na Polskę, tak głośno rozbrzmiewającego z akademickich i medialnych „elit” amerykańskich.

Uległ, to prawda, złudzeniu, że po rozpadzie Związku Sowieckiego być może uda się przyciągnąć Rosję ku standardom zachodniego świata - i z tego powodu opowiedział się przeciwko rozszerzaniu NATO o kraje Europy Środkowo-Wschodniej, sądząc, że może to obudzić na nowo ducha odwiecznej wrogości Rosji wobec Zachodu. Nikt lepiej niż on owego ducha nie opisał. I to zostanie, wraz z jego książkami, dłużej znacznie aniżeli jedna, błędna (i na szczęście nieskuteczna) polityczna diagnoza z końca lat dziewięćdziesiątych.

Pytałem kiedyś Richarda Pipesa o to, czy wpłynęła na jego widzenie Rosji i komunizmu polska tradycja analizy tych zjawisk, znaczona takimi nazwiskami jak Zygmunt Krasiński, Maurycy Mochnacki, Jan Kucharzewski. Odpowiedział wtedy (w 1991 r.), że wielkie, siedmiotomowe dzieło Kucharzewskiego Od biatego caratu do czerwonego zna tylko $\mathrm{z}$ anglojęzycznego, nienajlepszego, jednotomowego skrótu. Ktoś przysłał mu artykuły Mochnackiego z 1832 r. o metodach, jakimi Rosjanie rozszerzali swoje imperium. Zbieżność ze 150 lat późniejszymi analizami Pipesa była uderzająca. Krasińskiego przeczytał dopiero, gdy mu tę lekturę podpowiedziałem (oczywiście Profesor Pipes miał też znacznie lepszego niż ja "doradcę literackiego" na Harvardzie, w osobie profesora na katedrze polonistyki, Wiktora Weintrauba). Po latach, kiedy odbierał doktorat honorowy, przyznany mu przez Uniwersytet Warszawski, Profesor Pipes nawiązał do Krasińskiego uznając genialną trafność jego profecji łączącej już w połowie XIX stulecia Rosję z grozą komunizmu. Książki Richarda Pipesa prowadzą tę nić „polskiej szkoły”, a może raczej po prostu - polskiej wrażliwości - w wiek XXI. I za to jestem autorowi Rosyjskiej rewolucji szczególnie wdzięczny.

Ten pożegnalny szkic do portretu wielkiego historyka pozwolę sobie zakończyć jego odpowiedzią na moje pytanie, jak on rozumie przedmiot swoich badań, historię. Oto odpowiedź mądrego, doświadczonego człowieka:

To, co się dzieje w historii, jest tworzone przez człowieka. Nic nie jest nieuniknione. Będąc dwa lata przy Białym Domu, przekonałem się, że to prawda - wszystko, co tworzy historię, historię polityczną przynajmniej, to są decyzje ludzi i ludzie odpowiadają za swoje błędy, za swoją ignorancję. Pisanie historii jest dlatego tak ciekawe, że człowiek uczy się, czego nie robić, czego unikać. Oczywiście są też pewne siły czy uwarunkowania bezosobowe, one tworzą ramy, w których ludzie podejmują decyzje (nie można na przykład zrobić z Rosji kraju demokratycznego w ciągu jednego dnia czy miesiąca...). Dodałbym jeszcze, że nie wierzę w racjonalizację życia, w stworzenie takiego układu życia społecznego, w którym wszystko będzie funkcjonowało jak w szwajcarskim zegarku. Konflikty zawsze będą istnieć. Najlepszy system polega na tym, by dać ludziom żyć, by dać ludziom spokój. Tego rodzaju pogląd jest bardzo niepopularny wśród inteligencji, bo inteligencja lubi rządzić. Inteligencja jest bowiem taką międzynarodową klasą, którą łączy przekonanie, że zna tajniki dobrego rządu, że wie lepiej, czego ludziom potrzeba [...]. 
Tego spokojnego, roztropnego głosu historyka z Cieszyna (Warszawy, Harvardu) będzie nam brakować.

\section{Bibliografia}

\section{Wykorzystane źródła:}

Nowak A., Intelektualna historia III RP. Rozmowy z lat 1991-2012, Warszawa 2013, s. 35-48 (To imperium się rozpadnie - rozmowa z R. Pipesem z 5 IV 1991 r.) oraz s. 61-67 (Sita tradycji - rozmowa z R. Pipesem z 22 X 2004 r.).

Pipes R., Vixi. Memoirs of a Non-Belonger, New Haven - London 2003.

Pipes R., Rosja, komunizm i świat. Wybór esejów, red. A. Nowak, Kraków 2002.

Pipes R., 1917 and the Revisionists, „The National Interest” (1993), no. 31, s. 68-79.

Pipes R., Communism. A History, New York 2003.

Pipes R., Communism: The Vanished Specter, London - New York 1994.

\section{Opracowania:}

Daly J., The Pleiade: Five Scholars Who Founded Russian Historical Studies in America, „Kritika: Explorations in Russian and Eurasian History" 18 (2017), no. 4, s. 785-826.

Filipowicz M., Emigranci i Jankesi. O amerykańskich historykach Rosji, Lublin 2007.

Nowak A., Richard Pipes, w: Leksykon kultury polskiej poza krajem od roku 1939, red. K. Dybciak, Z. Kudelski, Lublin 2000, s. 325-326.

Nowak A., A "Polish Connection” in American Sovietology, Or the Old Homeland Enmities in the New Host Country Humanities, „Ab Imperio” (2007), no. 4, s. 237-259.

Nowak A., Unde malum? - E.H. Carr's and Richard Pipes' Visions of the Russian Revolution, w: East and West. History and Contemporary State of Eastern Studies, eds. J. Malicki, L. Zasztowt, Warszawa 2009 (Bibliotheca Europae Orientalis, 34; Didactica, 5), s. 77-102. 